\title{
Adatok a Dunántúl közösségi jelentőségü bogarainak ismeretéhez I.
}

\author{
ROZNER GYÖRGY \& LÖKKÖS ANDOR \\ Balaton-felvidéki Nemzeti Park Igazgatóság H-8229 Csopak, Kossuth u. 16. Hungary \\ e-mail: roznergyuri@gmail.com, a.lokkos@gmail.com
}

\begin{abstract}
Rozner, Gy. \& LöKkös, A.: Data to the European conservation importance beetles (Coleoptera) in Transdanubia, Hungary I.

Abstract: Our knowledge on Rhysodes sulcatus and Cucujus cinnaberinus was far from exhaustive and from the previous term we only had a short amount of data on the studied species, therefore the survey of new occurence of the examined species was our main aim. Between 2011 and 2018, 80 Natura 2000 sites in Transdanubia were surveyed. Cucujus cinnaberinus were documented in 556 sampling sites. The species was found in the majority of the sampling locations, so it is generally widespread and frequent in the examined territories. Rhysodes sulcatus was found in 130 sampling sites, mainly in South Trandanubia.
\end{abstract}

Keywords: Natura 2000 network, saproxylic beetle, Coleoptera, protected species, dead wood.

\section{Bevezetés}

Az erdők diverzitása Európa szerte egyre csökkenő tendenciát mutat. Ezt felismerve az Európai Unió jelentős számú erdei társulást és erdőkhöz kötődő fajt emelt a közösségi jelentőségű társulások és fajok közé, amelyek között számos szaproxilofág bogár fajt találunk.

A skarlátbogár (Cucujus cinnaberinus) Európa középső és északi részén elterjedt, valamint Olaszország néhány pontján fordul elö, de a legtöbb országban ritka (HoRák et al. 2010, VREZEC et al. 2017). Az IUCN vörös listája kipusztultnak jelzi a korábban ismert spanyolországi és Balkán-félszigeti állományait, így annak ellenére, hogy a faj nagy területen elterjedt, a Vörös listán „mérsékelten fenyegetett” (Near Threatened) kategóriában szerepel (NiETo et al. 2010). A faj visszaszorulása elsősorban az élőhelyek csökkenésével magyarázható (HoRÁK \& СНовот 2009, HoRÁK et al. 2010).

Hazánkban sok helyen elöfordul, egyes területeken gyakorinak tekinthetö (MERKL 2014). Az ország hüvösebb területein ritkább, az Aggteleken csak a közelmúltban került elő (Kovács et al. 2017). Minden olyan élőhelyen számíthatunk előfordulására, ahol száradó, vagy kiszáradt fák találhatóak, az élőhely minősége nem befolyásolja előfordulását. Szinte minden fafajban elöfordulhat, azonban előnyösebbek számára a vastagabb kérgü fafajok (nyár, füz, fenyő, idős éger). A jellemzően erdős területek mellett a faj számára alkalmas élőhelyet jelentenek az erdősávok, a magányos fák is (Rozner et al. 2016, RozNER \& LőKKös 2017). A fajt a Berni Egyezmény II. jegyzéke is tartalmazza és európai közösségi jelentőségü faj az élőhelyvédelmi irányelv II. és IV. függeléke szerint. 


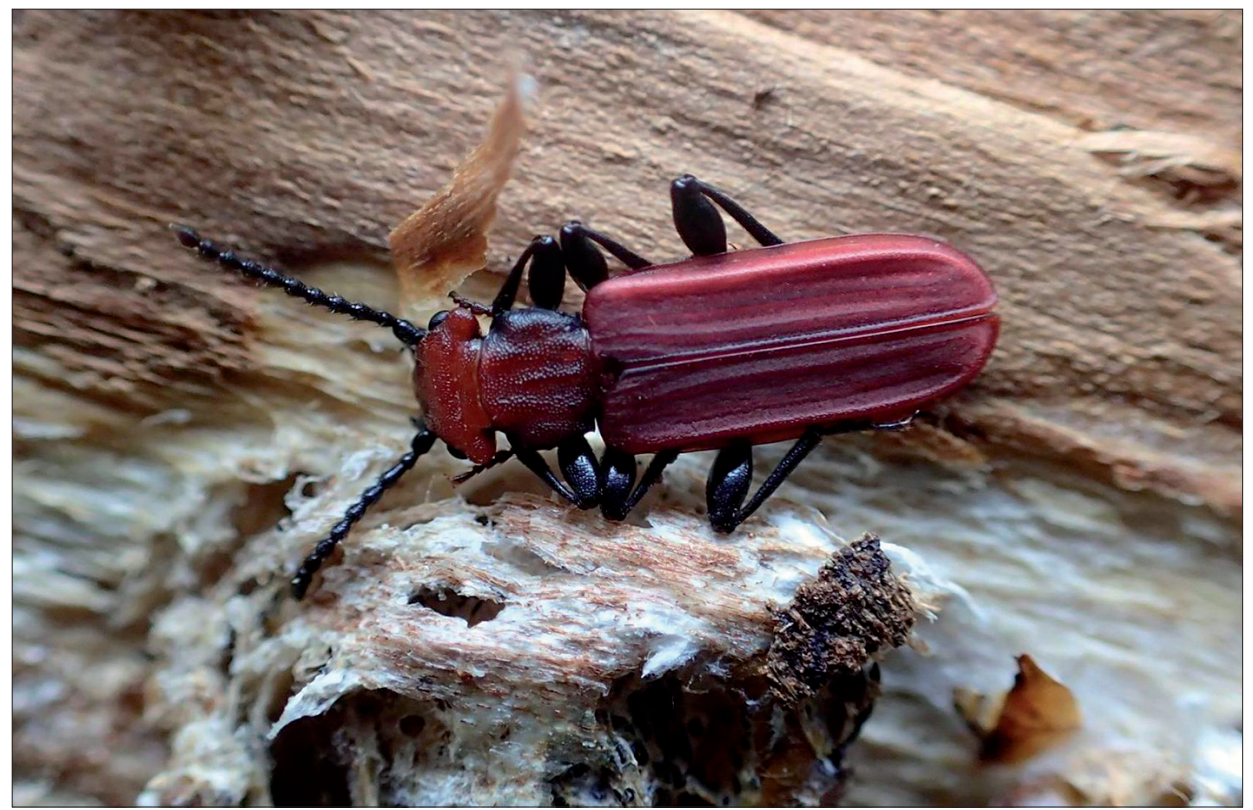

1. ábra: Skarlátbogár (Cucujus cinnaberinus) imágó

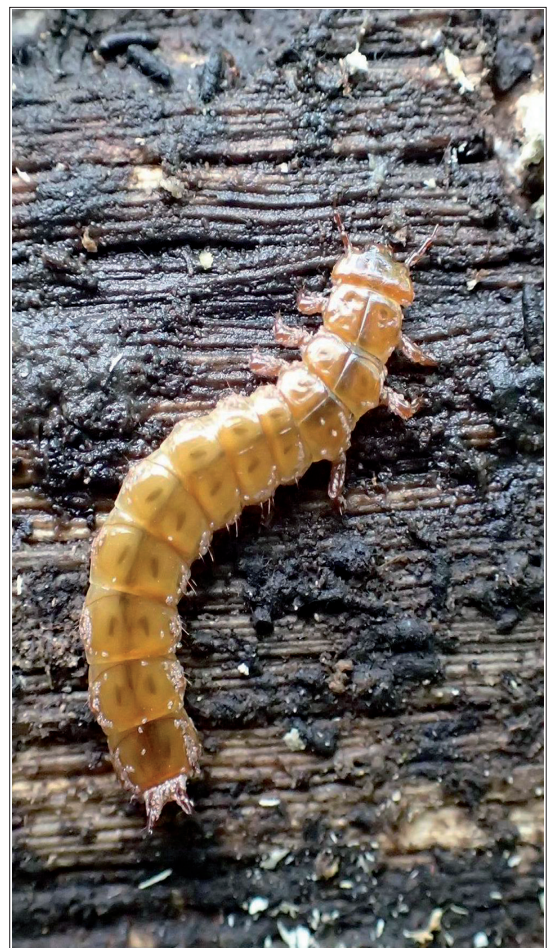

2. ábra: Skarlátbogár (Cucujus cinnaberinus) lárva 
A kerekvállú állasbogár (Rhysodes sulcatus) elterjedési területe Európán át NyugatSzibériáig terjed. Az IUCN vörös listája kipusztultnak jelzi több országban, illetve a nagyobb feltételezett elterjedés miatt az ,adathiányos” (Data Deficient) kategóriában szerepel (MENDEZ et al. 2010).

Magyarországi adatai az Északi- és a Dunántúli-középhegységből, a Köszegi-hegység néhány pontjáról, a Duna déli határszakaszáról, valamint Somogy és Zala megye számos lelöhelyéről származnak (SzÉL \& KUTASI 2014). A Dunától keletre rendkívül ritka, a Bükkből (Kovács et al. 2015), a Zempléni-hegységből (ÁDÁm 1994, Szél 1996) ismerjük, a Mátrából csak egy több, mint száz éves adatáról tudunk (KUTHY 1897). Ellentétben a hegyvidéki jellegü élőhelyekkel, ahol az adatok alapján szórványosan fordul elő és rendkívül ritka, addig Belső-Somogyban, a Dráva-mentén és Dél-Zalában kimondottan gyakori (SzÉL \& KUTASI 2014, RozNer et al. 2016, RozNER \& LöKKös 2017). A fajt a Berni Egyezmény II. jegyzéke tartalmazza és európai közösségi jelentőségü faj az élőhelyvédelmi irányelv II. és IV. függeléke szerint.

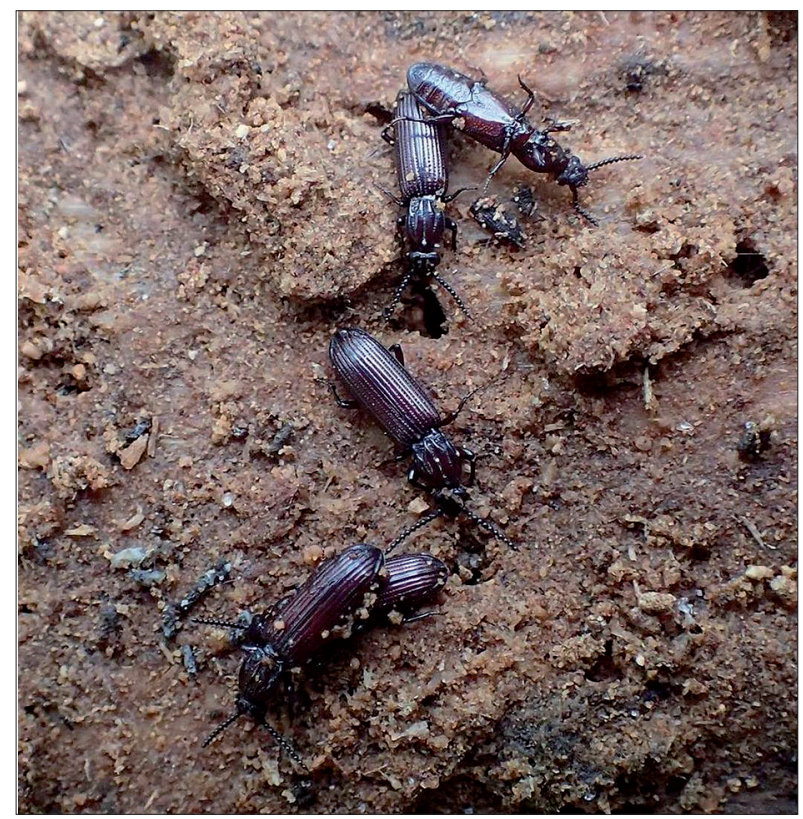

3. ábra: Fakéreg alatt párzó állasbogarak (Rhysodes sulcatus)

\section{Anyag és módszer}

A skarlátbogár (Cucujus cinnaberinus) és a kerekvállú állasbogár (Rhysodes sulcatus) mennyiségi mintavételezése, állományfelmérése és populációbecslése nem valósítható meg, mivel a mintavételezés az élőhely megrongálásával, illetve pusztulásával jár. Ezért vizsgálataink elsősorban a jelenlét/hiány megállapítására irányultak.

A skarlátbogár (Cucujus cinnaberinus) előfordulásának kimutatása alapvetően egyeléssel, a faj számára alkalmas kéreggel rendelkező elhalt fák kéreg alatti részének átvizsgálásával, kéreg lefejtésével történt.

A mintavételezés során elsősorban az élő lárvák felkutatására koncentráltunk, mivel azok egész évben, míg az imágók csak szezonálisan találhatók meg élöhelyükön. 
A kerekvállú állasbogár (Rhysodes sulcatus) esetében a mintavételezést egész évben folytattuk, azonban a könnyebb mintavételezés, valamint a két faj felmérésének összehangolása miatt a fö időszak a tavaszi nyár eleji időszak volt.

A többé kevésbé egyenletes mintavételezés és a megfelelő adatsürüség érdekében a mintavételezés alapját a 2,5×2,5 km-es UTM háló adta, az egyes négyzeteken belül az alkalmasnak tünő élőhelyeken kerestük a célzott fajokat. A vizsgálatok célja a Natura 2000 hálózathoz tartozó területek felmérése volt, ezért az adatok döntő többsége is ezekről származik.

A mintavételezés során a pontos lelöhely és GPS koordináta mellett rögzítettük az élőhely jellemzőit, az előfordulási állapotot, valamint a fafajt is.

\section{Eredmények}

A mintavételi helyek felsorolásánál a fajnév után a közigazgatási hovatartozás, majd a közelebbi lelőhely szerepel. Ezt követi a dátum és zárójelben az EOV koordináta. A lelőhelyek jegyzéke 2011.02.11. és 2018. 05.18. közötti adatokat tartalmaz.

Rövidítések:

lv - lárva, im - imágó

\section{Cucujus cinnaberinus (Scopoli, 1763)}

\section{Baranya megye}

Baranyahídvég, 2015.04.20. (EOV: 569008, 56722, 1v.); Drávafok, 2011.05.15. (EOV: 549687, 60927, im.); Drávaszabolcs, Dráva-part, 2015.04.20. (EOV: 585494, 49180, lv.); Drávasztára, Monyoró-erdő, 2014.08.03. (EOV: 554555, 54825, lv.); Felsőszentmárton, 2015.04.20. (EOV: 548183, 55958, lv., EOV: 546078, 56027, lv.); Felsőszentmárton, Dráva-part, 2015.04.20. (EOV: 545759, 55615, lv.); Hobol, Felső-liget, 2014.07.23. (EOV: 553944, 73669, 1v.); Kisszentmárton, 2015.04.20. (EOV: 572014, 51943, lv.); Matty, Dráva-part, 2015.04.20. (EOV: 590666, 46928, lv., im.); Nagyharsány, Harsányi-hegy, 2014.07.21. (EOV: 601816, 57181, lv.); Pettend, 2014.07.23. (EOV: 545993, 73929, lv.); Szentborbás, Dráva-part, 2015.04.18. (EOV: 541515, 58432, lv.); Vokány, 2014.07.21. (EOV: 594024, 61633, lv.)

\section{Győr-Moson-Sopron megye}

Rábakecöl, 2014.07.25. (EOV: 501617, 231442, lv.)

\section{Somogy megye}

Ádánd, Felső-hegy, 2012.12.10. (EOV: 582323, 168035, im.); Ádánd, Dömös-völgy, 2012.12.10. (EOV: 582412, 166868, lv., im.); Babócsa, 2014.07.19. (EOV: 516622, 75946, lv.), 2015.04.14. (EOV: 516887, 76187, 1v.); Babócsa, Erzsébet-sziget, 2015.04.14. (EOV: 516209, 74765, lv., EOV: 516184, 74777, lv.), 2018.04.15. (EOV: 516236, 74695, 1v.); Balatonberény, Cseri-erdő, 2012.10.24. (EOV: 518418, 150705, im.); Balatonboglár, Boglári Nagy-berek, 2013.03.13. (EOV: 542417, 158815, lv., EOV: 542580, 159223, lv.); Balatonendréd, Halastó-part, 2013.03.07. (EOV: 568458, 168689, lv.); Balatonfenyves, Községi legelö, 2013.03.20. (EOV: 527676, 151556, im.); Balatonkeresztúr, Felsőmelléki-legelő, 2012.10.03. (EOV: 522767, 151496, lv., EOV: 522799, 151421, lv.), 2013.04.11. (EOV: 523490, 151298, 1v.), 2013.10.17. (EOV: 524387, 150878, lv.); Balatonkeresztúr, 2015.09.05. (EOV: 519830, 150292); Balatonlelle, 2012.08.20. (EOV: 545945, 159531, lv.); Balatonőszöd, 2014.07.29. (EOV: 555240, 164830, lv.); Balatonőszöd, Öszödi-berek, 2015.04.07. (EOV: 556137, 162296, im.); Balatonszabadi, 2012.11.12.(EOV: 581826, 177446, 1v., im.); Balatonszentgyörgy, Bari-erdő,2012.03.27.(EOV:518078, 147401,1v.),2015.06.24.(EOV:518935, 147508,1v.); Balatonszentgyörgy, 2014.03.27. (EOV: 518528, 148964, lv., EOV: 518622, 148928, lv.); Balatonújlak, Vadaskerti-erdő, 2013.07.05. (EOV: 519407, 146218, im.), 2015.06.11. (EOV: 519432, 146393, im.); Barcs, 2018.04.15. (EOV: 


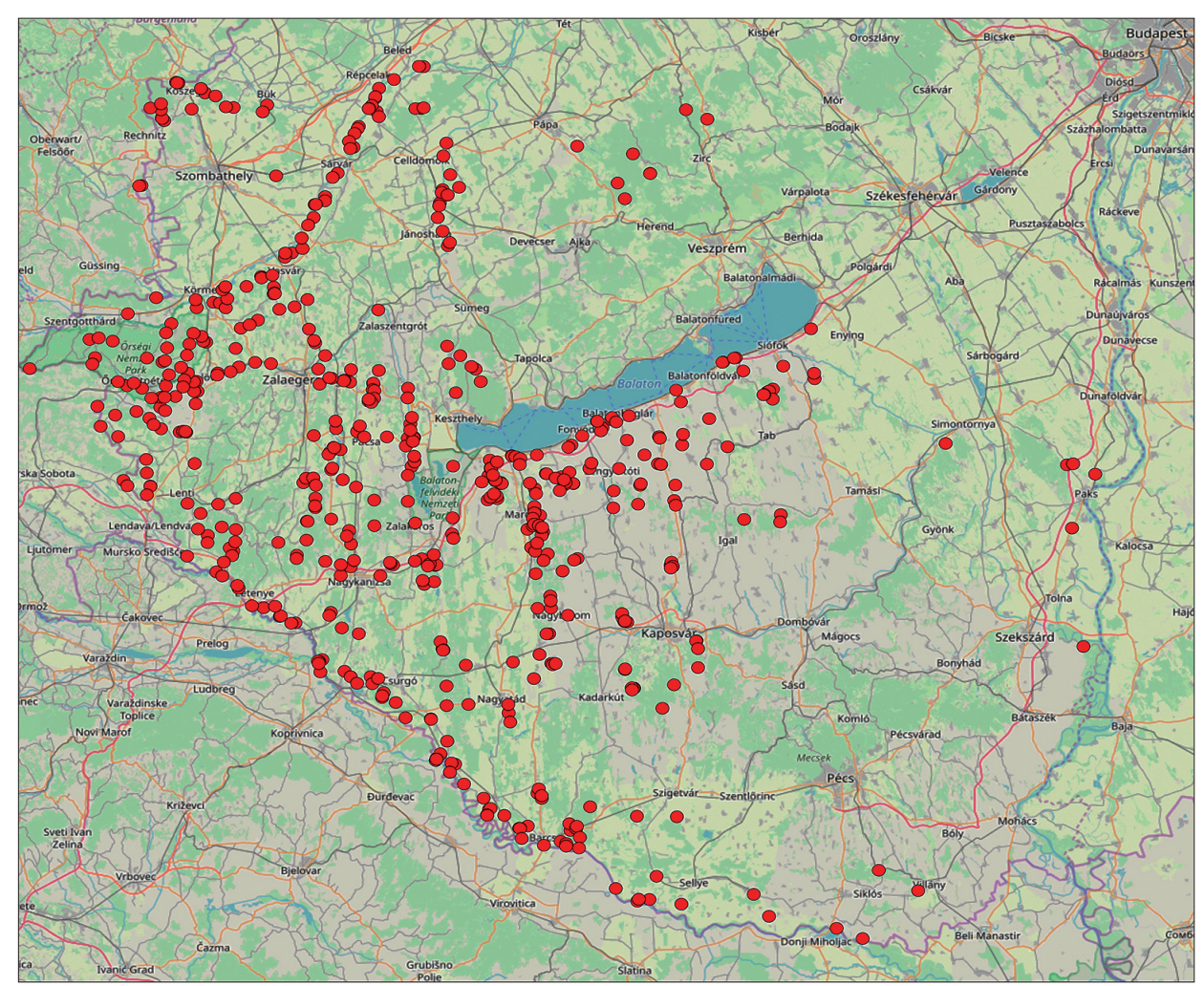

4. ábra: A skarlátbogár (Cucujus cinnaberinus) előfordulási adatai

522969, 69567, lv.); Barcs, Darányi-borókás, 2015.04.18. (EOV: 532734, 71129, im., EOV: 532530, 72578, lv., EOV: 533872, 71531, lv., EOV: 534006, 71986, im., EOV: 534564, 69589, lv.); Barcs, Dráva-part, 2015.04.18. (EOV: 527375, 68012, 1v.); Barcs, Kis-Bók, 2015.04.18. (EOV: 530727, 68789, lv., EOV: 531848, 68292, lv.), 2018.04.15. (EOV: 531791,67737, lv.); Barcs, Ferenc-telep, 2015.04.14. (EOV: 524245, 72239, im.), 2018.04.15. (EOV: 522545, 71802, lv.,EOV: 522682, 71788, lv., EOV: 522671, 71735, lv.); Bárdudvarnok, Bárdi-patak völgye, 2011.02.08. (EOV: 544196, 105602, im.); Bélavár, Kerék-hegy, 2015.04.13. (EOV: 508663, 90824, lv.), 2018.04.15. (EOV: 508630,90839, lv); Bélavár, Dráva ártér, 2011.02.27. (EOV: 506405, 87131, im.), 2018.04.15. (EOV507208, 88070, lv.), 2018.04.15. (EOV: 506410, 87017, 1v.), 2018.04.15. (EOV: 506436, 87015, lv.), 2018.04.15. (EOV: 506440, 87014, lv.), 2018.04.15. (EOV: 507209, 88144, lv.), 2018.04.15. (EOV: 506418, 87008, lv.); Bélavár, Dráva-part, 2015.04.13. (EOV: 506258, 86723, lv.); Beleg, Keresztúti-erdő, 2012.11.03. (EOV: 527338, 108992, im.); Berzence, 2011.02.27. (EOV: 500491, 96050, im.); Berzence, Alsó-Gyóta-erdő, 2013.04.30. (EOV: 508705, 98459, 1v.); Bolhás, 2013.04.07. (EOV: 512698, 107033, lv.); Bolhó, 2015.04.14. (EOV: 515561, 78416, lv.); Böhönye, Balogdi-erdő, 2017.07.15. (EOV. 527158, 118910, lv.); Buzsák, Medvogya-patak völgye, 2012.01.10. (EOV: 534723, 145319, lv., EOV: 534678, 145352, im.); Buzsák, Kund-puszta, 2013.05.07. (EOV: 533982, 147766, 1v.); Buzsák, Terlakócaerdő, 2012.03.07. (EOV: 537966, 148495, lv.); Cserénfa, Tótfalusi-erdő, 2014.08.10. (EOV: 558640, 105637, 1v.); Cserénfa, Nádasdi-erdő, 2014.08.10. (EOV: 558690, 109690, lv.); Csoknyavisonta, fáslegelö, 2011.05.14. (EOV: 527155, 78690, im.), 2013.07.15. (EOV: 526324, 79260, lv., EOV: 527136, 78126, lv.), 2014.08.03. (EOV: 526598, 80189, lv.); Csuró, Lankóci-erdő, 2015.04.12. (EOV: 498648, 99366, lv., EOV: 496292, 101577, lv.); Drávatamási, Dráva-part, 2015.04.18. (EOV: 534354, 67278, lv.); Fiad, Kéri-erdő, 2012.11.07. (EOV: 554775, 144685, lv.); Fonyód, Bozót, 2013.05.07. (EOV: 534508, 153547, lv., im.); Fonyód, Széchenyiárok mente, 2013.05.07. (EOV: 533893, 153065, 1v., im.); Fonyód, Bézsényi-bozót, 2013.05.10. (EOV: 536668, 155444, 1v.); Fonyód, Ordacsehi-berek, 2012.11.16. (EOV: 539606, 158495, im.); Fonyód, 
Fonyódliget, 2014.03.18. (EOV: 539681, 158492, 1v.); Gamás, Vadéi-erdő, 2012.11.07. (EOV: 554483, 141395, lv.), 2013.03.11. (EOV: 554779, 140361, lv.); Gyékényes, Lankóci erdő, 2014.07.27. (EOV: 495941, 100522, lv.), 2015.04.12. (EOV: 495976, 100873, lv.); Hács, Ökörtilosi-erdő, 2012.09.26. (EOV: 547838, 144741), 2012.11.07. (EOV: 547979, 145064, lv., im.); Heresznye, Dráva-part, 2015.04.14. (EOV: 511743, 81550, lv.); Hetes, Pati-erdő, 2012.11.20. (EOV: 544784, 115618, lv.), 2013.04.13. (EOV: 543792, 116793, lv.), 2013.04.29. (EOV: 543818, 117437, lv.), 2015.03.18. (EOV: 544364, 115856, lv.); Hollád, 2012.10.31. (EOV: 516713, 146056, lv.); Hosszúvíz, 2013.03.23. (EOV: 526923, 131051, im.); Hosszúvíz, Cserfekvés, 2013.03.23. (EOV: 529377, 130458, im., EOV: 528532, 129043, lv.); Istvándi, Szállás-tói erdő, 2015.04.18. (EOV: 536730, 76120, lv.); Kapoly, Madarasi-erdő, 2013.07.10. (EOV: 565154, 152670, lv.); Kaposfö, Patierdő, 2012.11.20. (EOV: 544225, 115745, lv.), 2013.04.13. (EOV: 543999, 116365, im.); Karád, Karádi-erdő, 2013.06.18. (EOV: 556251, 153169); Karád, 2013.03.11. (EOV: 561047, 149019, 1v.); Kaszó, 2013.04.07. (EOV: 507804, 112183, lv.); Kereki, Erzsébet-erdő, 2015.04.17. (EOV: 561638, 158676, 1v.); Kéthely, Vadaskerti-erdő, 2012.10.26. (EOV: 520456, 145731, lv., EOV: 520468, 145889, lv.); Kéthely, Felső-Gyulavár, 2014.03.27. (EOV: 519727, 142432, lv., EOV: 519573, 143011); Kéthely, Vadaskerti-erdö, 2014.07.18. (EOV: 520382, 145572, EOV: 520683, 145633, lv.), 2015.06.25. (EOV: 519050, 143476, lv.); Kéthely, Sári-erdő, 2014.03.06. (EOV: 526202, 145631, lv.); Kéthely, Nagy-berek, 2014.03.11. (EOV: 524276, 149589, 1v.); Kisbajom, 2012.11.03. (EOV: 529636, 107068, lv.); Kisberény, 2012.11.07. (EOV: 542628, 143630, 1v.); Kutas, Gyótai-erdő, 2013.07.14. (EOV: 528807, 113383, 1v.); Látrány, Birkás legelő, 2013.02.25. (EOV: 551725, 155001, im.), 2015.05.06. (EOV: 551895, 154637, lv.); Lengyeltóti, 2013.05.10. (EOV: 538363, 149643, lv.); Lengyeltóti, Kék-tó, 2013.03.18. (EOV: 543741, 148395, 1v.); Lipótfa, 2014.08.10. (EOV: 544181, 105451, lv.); Magyaregres, Mernyei-erdő, 2015.07.21. (EOV: 553994, 127326, 1v.); Marcali, 2017.02.08. (EOV: 526578, 138087, lv.), 2017.02.20. (EOV: 526607, 136478, lv., EOV: 526867, 136840,1v.); Marcali, Bize, 2013.03.23. (EOV: 525496, 135770, lv.); Marcali, Boronka, 2012.10.26. (EOV: 526882, 139963, lv., EOV: 526970, 140580, lv., EOV: 528045, 138689, lv.), 2017.02.08. (EOV: 526934, 139236, lv.); Marcali, Gyótai-erdő, 2017.03.09. (EOV: 527339, 132821, lv.); Marcali, Marcali-tározó, 2012.10.30. (EOV: 527360, 143332, im.); Marcali, Nagy-Gyóta, 2013.03.09. (EOV: 528585, 135183, 1v., im., EOV: 528280, 134417, lv.); Marcali, Nagy-Gyótai-erdő, 2017.02.20. (EOV: 528051, 136154, lv., EOV: 528056, 136161, 1v., EOV: 527801, 136584,lv., 528390, 136131, lv.); Mernye, Mernyei-erdő, 2013.08.05. (EOV: 553601, 127627, lv., EOV: 553611, 127673, lv., EOV: 553750, 128239, lv.); Mesztegnyö, 2013.03.23. (EOV: 526161, 131899, lv.); Mesztegnyő, Alsójárás, 2013.07.17. (EOV: 526919, 126286, lv.); Mesztegnyő, Kak-puszta, 2013.07.17. (EOV: 532249, 126743, lv.); Nagyatád, Rinya-part, 2011.02.27. (EOV: 520920, 98438, im.); Nagyatád, 2012.11.03. (EOV: 520950, 96620); Nagybajom, Homok-puszta, 2013.07.17. (EOV: 529791, 118883, 1v.); Nagybajom, Csikóta-puszta, 2013.07.17. (EOV: 529710, 121467, lv.), 2017.07.15. (EOV: 529757, 120436, lv.); Nagybajom, Újmajor, 2012.06.02. (EOV: 533126, 117302, lv., im.); Nagybajom, Gyótai-erdő, 2012.11.03. (EOV: 529318, 113395, lv.); Nagycsepely, 2015.12.28. (EOV: 556453, 155449, im.); Nagykorpád, 2012.11.03. (EOV: 529862, 106756, lv., EOV: 530466, 106986, lv.); Ordacsehi, Ordacsehi-berek, 2012.10.05. (EOV: 540655, 157129, lv., im., EOV: 540356, 156414, im.); Ordacsehi, Jamai-patak mente, 2013.03.20. (EOV: 543369, 158249, lv.); Örtilos, Dráva ártér, 2011.02.27. (EOV: 483599, 108141, im.); Örtilos, Dráva-part, 2015.04.12. (EOV: 483464, 108645, lv., EOV: 483866, 106294, 1v.); Örtilos, Látó-hegy, 2013.04.30. (EOV: 484319, 108947, lv.), 2013.07.15. (EOV: 483679, 108552, 1v.); Ötvöskónyi, 2013.07.14. (EOV: 522019, 107492, lv.); Péterhida, 2018.04.15. (EOV: 519609, 74616, lv.); Porrogszentkirály, 2011.02.27. (EOV: 495299, 104612, im.), 2013.04.30. (EOV: 493821, 105043, lv.), 2014.07.27. (EOV: 494087, 103497, 1v.), Rinyaszentkirály, Magas-erdő, 2013.07.14. (EOV: 521209, 94641, lv.); Ságvár, Jaba-völgy, 2014.02.26. (EOV: 574216, 164802, im., EOV: 573136, 164220, lv.), 2014.07.16. (EOV: 573449, 164365, lv.); Ságvár, Böre-vár, 2014.07.16. (EOV: 574164, 162640, lv., EOV: 572472, 163648, lv., EOV: 572353, 163592, lv.); Sántos, Nádasdi-erdő, 2014.08.10. (EOV: 558429, 111413, lv., EOV: 558350, 111354, 1v.); Siófok, Kiliti, 2012.12.10. (EOV: 576294, 169630, lv., im.); Somogyacsa, Bükk-kúti erdő, 2013.06.21. (EOV: 568212, 137143, lv.); Somogyaszaló, Mernyei-erdő, 2015.07.21. (EOV: 553605, 126980, 1v.); Somogyfajsz, 2013.08.05. (EOV: 535219, 129360, lv., EOV: 534562, 129024, lv.); Somogysámson, Felső-Gyulavár, 2014.03.27. (EOV: 517806, 142196, lv.), 2015.06.23. (EOV: 518365, 142787, lv.); Somogyszentpál, Felső legelő, 2012.10.09. (EOV: 529369, 147541, im., EOV: 529533, 147512, lv.); Somogyszentpál, Varjaskéri-legelö, 2012.10.09. (EOV: 531266, 146583, im.); Somogyszentpál, Marcali-tározó, 2012.10.30. (EOV: 527124, 144397, lv.); Somogytúr, Tardi-erdő, 2012.09.26. (EOV: 551420, 149250, lv., im.), 2015.07.16. (EOV: 552011, 149075, lv., EOV: 552009, 149120, lv.); Somogyudvarhely, 2015.04.13. (EOV: 505516, 95706, lv., EOV: 505533, 95570, 1v.); Somogyvár, Vityai-erdő, 2013.07.09. (EOV: 547377, 140705, lv.); Somogyvár, Kupa-vár-hegy, 2013.03.18. 
(EOV: 542486, 140024, 1v., im.); Szabás, Égett-berek, 2012.11.03. (EOV: 526109, 103867, im.); Szenna, Mátyás-kút, 2012.05.29. (EOV: 545904, 101456, 1v., EOV: 545823, 101347, lv.); Szenna, Denna-erdő, 2014.08.10. (EOV: 545460, 101519, lv., EOV: 545486, 101043, 1v.); Szenta, 2013.04.07. (EOV: 508170, 110600, im., EOV: 508354, 110356, lv., EOV: 508270, 110317, 1v.); Szenta, Nagy-Krató-erdő, 2013.07.18. (EOV: 508783, 102650, lv.); Szőkedencs, Vár-domb, 2012.03.04. (EOV: 510652, 135105, lv., im.); Szőkedencs, 2012.06.26. (EOV: 510810, 138548, lv.), 2014.03.27. (EOV: 510847, 134143, lv.); Szőllősgyörök, Kopasz-berek, 2012.03.06. (EOV: 545409, 154380, lv., im.); Szőlösgyörök, Pirosház, 2013.07.08. (EOV: 548814, 151193, lv.); Tarany, Hóka-malom, 2013.07.18. (EOV: 513018, 98597, 1v.); Táska, Martonos, 2012.05.08. (EOV: 532880, 145040, lv.); Táska, Fehérvíz-puszta, 2012.07.27. (EOV: 533179, 145588, 1v.); Táska, 2012.10.09. (EOV: 532463, 146866, lv., im.); Táska, Nekota, 2013.03.04. (EOV: 532016, 143874, im.), 2013.05.24. (EOV: 532905, 146181, 1v.); Törökkopány, Polgári-erdő, 2013.07.13. (EOV: 575435, 138089, lv.), 2014.03.20. (EOV: 575295, 136489, lv.); Vízvár, vasútállomás, 2011.02.27. (EOV: 510076, 85856, im.); Vízvár, Dráva-part, 2015.04.13. (EOV: 509036, 84093, lv.); Vízvár, Dráva ártér, 2018.04.15. (EOV: 509374, 86134, lv.), 2018.04.15. (EOV: 509023, 84155, lv.); Zákány, 2013.04.30. (EOV: 489868, 105102, 1v.), 2013.07.15. (EOV: 489854, 105099, lv.); Zákány, Vázsony-puszta, 2013.07.15. (EOV: 491081, 103672, 1v.); Zákányfalu, Izidorus-patak, 2013.04.30. (EOV: 488663, 106322, 1v.); Zamárdi, Brettyó, 2011.04.06. (EOV: 564394, 170590, im.); 2012.12.10. (EOV: 564533, 170657, im.); Zamárdi, 2011.04.06. (EOV: 566700, 171440, im.); 2012.11.12. (EOV: 567024, 171520, lv., im.); Zselickisfalud, Enyezdi-erdő, 2014.08.10. (EOV: 551450, 97016, lv.); Zselickislak, Kislaki-erdö, 2014.08.10. (EOV: 553851, 102026, lv.)

\section{Tolna megye}

Öcsény, Gemenc, 2011.02.11. (EOV: 634935, 109483, im.); Paks, Gyapa, 2011.02.11. (EOV: 631782, 148243, im., EOV: 633028, 148475, im.); Paks, Dunakömlőd, 2011.02.11. (EOV: 637340, 146257, im.); Paks, Dunaszentgyörgyi láperdö, 2011.02.11. (EOV: 632756, 134776, im.); Tolnanémedi, 2011.02.11. (EOV: 608004, 152901, im.)

\section{Vas megye}

Acsád, Acsádi-erdő, 2015.08.01. (EOV: 475956, 225350, lv.); Alsóújlak, 2014.07.26. (EOV: 482884, 196390, 1v.); Andrásfa, 2013.05.09. (EOV: 478001, 183683, lv.); Boba, 2013.08.04. (EOV: 509855, 205229, lv., EOV: 510293, 207517, lv.), 2015.03.13. (EOV: 509746, 204704, lv.); Bozsok, Sötét-völgy, 2014.07.24. (EOV: 456799, 224122, lv., EOV: 456368, 224657, lv.); Bozsok, 2015.04.21. (EOV: 456781, 224104, lv., EOV: 456436, 224614, lv.); Bük, 2015.04.13. (EOV: 476870,226790, lv.); Csákánydoroszló, 2015.04.03. (EOV: 454026, 186885, lv.); Csöde, Úr-erdő, 2018.04.19: (EOV: 458665, 167799, 1v.); Csöde, Zala-part, 2018.04.19. (EOV: 458942, 169305, lv.); Csönge, 2014.07.25. (EOV: 498098, 224840, lv.); Csörötnek, Huszászi-patakvölgye, 2017.07.29,(EOV: 445229,177999, lv.); Daraboshegy, Csonka erdő, 2017.08.05,(EOV: 460196,176877, lv., 461064, 179128, lv.); Döröske, 2014.08.05. (EOV: 471729, 188707, 1v.), 2014.11.21. (EOV: 471728, 188690, lv., im.); Egyházashollós, Hollósi-erdő, 2014.08.05. (EOV: 474676, 190735, lv., EOV: 474722, 190465, lv.); Felsőcsatár, 2015.03.26. (EOV: 451931, 210636, lv., EOV: 451486, 210559, lv.); Felsőszölnök, Lujza-hegy, 2018.04.21. (EOV: 428787, 172755, 1v.); Győrvár, 2013.05.09. (EOV: 480977, 184118); Halastó, 2013.10.23. (EOV: 470370, 179889, lv.); Halogy, 2014.11.20. (EOV: 461862, 184522, im.); Hegyhátszentjakab, 2018.04.19. (EOV: 459724, 170729, lv., EOV: 458399, 171985, lv.); Ikervár, 2014.07.26. (EOV: 487611, 207211, lv., EOV: 487535, 206296, lv., EOV: 489153, 211193, lv.); Ispánk, 2018.04.21. (EOV: 451776, 174155, lv.); Ivánc, Ménes-telep, 2017.08.05, (EOV: 463486,177174, lv.); Ivánc, 2018.04.19. (EOV: 455717, 179392, lv.); Ivánc, Ménes-telep, 2017.08.04. (EOV: 456784, 181292, lv.); Jákfa, 2015.04.23. (EOV: 494519, 221803, lv.); Karakó, 2013.08.04. (EOV: 510280, 199344, lv.); Katafa, 2014.11.20. (EOV: 466454, 185344, lv., im.); Kemenespálfa, 2013.08.04. (EOV: 509399,202205, lv.); Kenyeri, 2014.07.25. (EOV: 506689, 225223, lv.), 2015.03.25. (EOV: 505607, 225267, lv., EOV: 507195, 225383, lv.); Kercaszomor, Szomoróc, 2018.04.23. (EOV:441726, 164287, lv.); Kisrákos, 2018.04.19. (EOV: 454801, 173243, lv., EOV: 455317, 173507, lv.); Körmend, 2015.03.03. (EOV: 461708, 186221, lv.), 2015.03.19. (EOV: 466996, 188126, lv., EOV: 467608, 188782, lv.); Kőszeg, Köszegi-erdő, 2014.07.24. (EOV: 464176, 230621, lv.); Kőszeg, 2015.04.21. (EOV: 462202, 226358, lv.), 2015.04.24. (EOV: 459565, 231973, lv., EOV: 464928, 229662, lv., EOV: 466930, 228984, 1v., EOV: 464140, 230621, lv., EOV: 459817, 231902, 1v., EOV: 459394, 232099, 1v.), 2015.04.25. (EOV: 456303, 227696, lv.); Magyarföld, Konoka-erdő, 2018.04.19. (EOV: 445168, 162301, lv.); Magyarszombatfa, Ritási-domb, 2018.04.23. (EOV: 442208, 160003, 1v.); Meggyeskovácsi, 2014.07.26. (EOV: 485515, 205594, lv., EOV: 485517, 205588, lv., EOV: 485734, 205620, lv., EOV: 485249, 202856, lv.); 
Mersevát, 2015.03.11. (EOV: 511463, 217867, lv.); Nádasd, 2014.08.05. (EOV: 465181, 185517, 1v.); Nagymizdó, 2014.11.20. (EOV: 467542, 184278, lv.), 2014.11.21. (EOV: 467901, 186252, lv.); Nagyrákos, Öreg-hegy, 2018.04.19. (EOV: 452395, 165691, lv.); Nemeskocs, 2013.08.04. (EOV: 510497, 208089, 1v.); Nick, 2015.04.12. (EOV: 498650, 229704, lv., EOV: 497871, 227632, lv., EOV: 497887, 227931, lv., EOV: 497171, 226112, lv., EOV: 496578, 225504, im., EOV: 496555, 225454, lv.); Ostffyasszonyfa, 2015.03.24. (EOV: 498481, 223719, lv.); Örimagyarósd, 2017.08.05. (EOV: 459625, 174511, lv., EOV: 460196, 176877, lv.), 2017.08.06, (EOV: 455303, 168178,lv); Öriszentpéter, 2018.04.19. (EOV: 449042, 168987, lv. EOV: 445960, 169378,lv.), 2018.04.23. (EOV: 447717, 168439, lv.); Öriszentpéter, Öreg-hegy, 2017.08.06, (EOV: 450633,167795, lv.); Pankasz, 2017.08.06. (EOV: 455303, 168178, 1v.), 2018.04.19. (EOV: 455979, 170495, lv.); Pápoc, 2015.04.11. (EOV: 507432, 233995, lv., EOV: 506529, 234112, lv.); Rábapaty, 2015.04.23. (EOV: 494277, 221313, lv., EOV: 493662, 220312, im., EOV: 492556, 218696, 1v.); Rum, 2015.03.21. (EOV: 482767, 198606, lv.), 2015.04.26. (EOV: 484118, 201267, lv.); Sárfimizdó, 2013.05.09. (EOV: 473739, 181533), 2013.10.23. (EOV: 472075, 180594, lv.); Sárvár, 2014.07.07. (EOV: 493394, 217425, lv.), 2015.04.10. (EOV: 490153, 212091, lv.); Sárvár, Sitkei erdő, 2015.07.19. (EOV: 492768, 217179, lv.); Szalafö, Állami-erdő, 2018.04.21. (EOV: 441645, 174601, lv., EOV: 441080, 173259, lv.); Szatta, 2017.08.06, (EOV: 454337, 165789, lv., EOV: 454967, 165754, lv.); Szentgothárd, Hársas-patak-völgye, 2017.07.29., (EOV: 440698,178493, lv.); Szentgothárd, Vörös-hegy, 2018.04.21. (EOV: 442498, 178754, lv.); Szőce, Csonka erdő, 2017.08.05, (EOV: 462614,178428, lv., EOV: 462922,177370, lv.); Szőce, Rimány,2017.08.05. (EOV: 463486, 177174,lv.); Tömörd, 2015.04.13. (EOV: 470346, 226452, im., EOV: 468873, 226617, lv.); Vasvár, 2014.07.26. (EOV: 480787, 195515, lv., EOV: 479412, 194640, 1v.), 2014.11.26. (EOV: 479485, 195529, im., 2015.04.30. (EOV: 474717, 190409, lv., im., EOV: 476844, 190942, lv., EOV: 477062, 188400, lv., EOV: 476993, 186947, lv., EOV: 477161, 187133, lv., EOV: 477215, 187039, im.); Vasszentmihály, 2015.04.04. (EOV: 448342, 183669, lv.); Velem, 2015.04.22. (EOV: 456254, 226421, lv., EOV: 454227, 226856, 1v.); Velemér, Veleméri-hegy, 2017.08.06, (EOV: 445586, 157719, lv.); Vép, 2015.04.23. (EOV: 478178, 211841, lv.); Viszák, 2018.04.19.) (EOV: 455767, 176216, lv.)

\section{Veszprém megye}

Bakonybél, Gerence-völgy, 2018.05.10. (EOV: 550926, 210690, lv., EOV: 550946, 210643, lv.); Bakonyszentkirály, Cuha-völgy, 2018.05.10. (EOV: 558111, 223954, lv.); Csehbánya, 2018.05.18. (EOV: 545907, 205440, lv.); Csesznek, Alsó-erdő, 2018.05.27. (EOV: 562188, 221901, lv.); Csögle, 2015.03.11. (EOV: 513704, 208500, lv.); Egeralja, 2013.08.04. (EOV: 512042, 211213, lv.); Külsővat, 2013.08.04. (EOV: 510800, 215171, lv.); Nagypirit, 2013.08.04. (EOV: 511433, 206922, lv.), 2015.03.13. (EOV: 511441, 206953, lv.); Nagytevel, 2018.05.08. (EOV: 536855, 216689,lv.); Németbánya, 2018.05.18. (EOV: 544555, 208772, lv.); Sümeg, 2016.07.02. (EOV: 516380, 178662, lv.); Ugod, 2018.05.18. (EOV: 547652, 214846, lv.); Uzsa, Istvándi-erdő, 2016.10.28. (EOV: 519274, 173718, lv., EOV: 519059, 173904, 1v.)

\section{Zala megye}

Alsónemesapáti, 2014.01.13. (EOV: 487823, 168785, lv.), 2014.01.20. (EOV: 487382, 168902, 1v.), 2013.11.08. (EOV: 490255, 168346, lv., EOV: 490169, 168184, lv.); Alsószenterzsébet, 2013.05.14. (EOV: 454051, 159082, im.); Bagod, 2012.08.01. (EOV: 476024, 172238, lv.); Bocska, 2013.04.04. (EOV: 486912, 138873, lv.); Bondocfölde, 2013.04.16. (EOV: 472938, 172600, lv.); Borsfa, Haraszti- erdő, 2012.11.10. (EOV: 476353, 134194, lv.); Bödeháza, 2013.04.12. (EOV: 446300, 148362, 1v.), 2014.12.18. (EOV: 447042, 147204, lv.); Bucsuta, 2013.04.18. (EOV: 482267, 138523, lv., EOV: 482130, 138569, lv., EOV: 482130, 138569, lv., EOV: 482267, 138523, lv.); Cserszegtomaj, 2017.03.25. (EOV: 512086, 165134, im.); Csöde, 2013.05.14. (EOV: 457115, 165857, lv.), 2017.08.04, (EOV: 456784,181292, lv.); Csömödér, 2012.05.07. (EOV: 464782, 142689, lv.); Csörnyeföld,2013.05.15. (EOV: 466768, 133329, lv.), 2016.09.30. (EOV: 465513, 130312, lv.), Csörnyeföld, Basai-erdö, 2012.05.07. (EOV: 467425, 132610, lv.), 2014.11.13,(EOV: 467166, 131661, lv.); Egervár, 2013.05.09. (EOV: 483646, 179332, im.); Esztergályhorváti, 2015.04.24. (EOV: 503032, 149695, im., EOV: 502220, 147813, im.); Felsőszenterzsébet, 2013.05.14. (EOV: 452633, 160011); Fityeház, 2015.08.02. (EOV: 485988, 118338); Galambok, 2013.07.18. (EOV: 504890, 124485, lv.); Hahót, Fakospuszta alsó, 2012.05.30. (EOV: 487196, 149384, lv., EOV: 487428, 149758, lv.); Homokkomárom, 2015.01.14. (EOV: 488544,129111, lv.); Kálócfa, 2013.05.14. (EOV: 457703, 158298, EOV: 458356, 158442), 2016.03.05. (EOV: 458967, 158194, EOV: 458825, 158387); Kehidakustány, 2013.04.29. (EOV: 502725, 166295, im., EOV: 502725, 166295, im.); Kerecseny, 2016.01.24. (EOV: 495492, 142701); Kerkabarabás, 2013.05.14. (EOV: 460402, 151507); Kerkafalva, 2013.05.08. (EOV: 454060, 163648, lv.), 2013.05.14. (EOV: 
454982, 162882); Kerkaszentkirály, 2014.12.18. (EOV: 461242, 140839, 1v.); Keszthely, Kis-Balaton, 2012.01.24. (EOV: 511166, 149552, im.); Keszthely, Kő-hát, 2017.03.25, (EOV: 512086, 165134, im.); Kilimán, 2013.04.04. (EOV: 491986, 145597, 1v.); Kiscsehi, 2013.05.15. (EOV: 467892, 134590, 1v.); Lendvajakabfa, 2013.04.12. (EOV: 450918, 152682, 1v.); Lenti, 2013.05.10. (EOV: 458718, 143065); Letenye, 2013.10.21. (EOV: 473074,120354, lv., EOV: 470746, 120843, lv., EOV: 468227, 124654, lv.), 2015.04.30. (EOV: 475326, 120603, 1v.); Lovászi, 2014.11.13. (EOV: 460612, 137546, lv.); Magyarföld, 2013.05.14. (EOV: 449367, 162936); Magyarszentmiklós, 2014.04.28. (EOV: 489891, 135171, lv.); Magyarszerdahely, 2013.04.04. (EOV: 490375, 136386); Miháld, 2016.11.07. (EOV: 504590, 125335, lv.); Molnári, ártér, 2012.10.12. (EOV: 479254, 116952, lv.); Molnári, Mura part, 2016.10.10. (EOV: 478410, 116894, 1v.); Murarátka, 2013.10.21. (EOV: 468039, 125265, lv.); Muraszemenye, 2012.11.21. (EOV: 463946, 128286, 1v.), 2016.10.10,(EOV: 465115, 127383); Nagygörbö, 2016.10.17. (EOV: 506948, 176708, lv); Nagykanizsa, Korpavár, 2013.10.29. (EOV: 490691, 133438, lv.); Nagykanizsa, 2013.04.24. (EOV: 490477, 128568, 1v.), 2014.01.14. (EOV: 488467, 126804, 1v.); Nagykanizsa, Palin, 2015.01.27. (EOV: 491163, 129965, 1v.); Nagykanizsa, Csónakázó-tó, 2016.03.05. (EOV: 496256, 126550); Nagykanizsa, Mórichely, 2016.04.10. (EOV: 488381, 115599); Nagykapornak, 2012.01.13. (EOV: 495898, 167535, im.), 2013.04.15. (EOV: 491397, 167886), 2016.04.16. (EOV: 495429, 163457, EOV: 494960, 164158); Nagykapornak, Remete-kert, 2013.03.20. (EOV: 494924, 163736, lv., EOV: 495974, 167462, 1v.), 2014.01.20. (EOV: 495947, 167552, 1v., EOV: 495809, 166151, lv., EOV: 496120, 165944, lv.), 2014.04.14. (EOV: 496034, 164320, im.); Nagyrada, 2014.02.27. (EOV: 502099, 142272, lv.); Nagyrécse, fás legelő, 2015.05.06. (EOV: 495365, 137250, 1v.); Nagyrécse, 2014.05.09. (EOV: 498840, 128799, 1v.), 2016.03.26. (EOV: 498311, 129141), 2016.04.10. (EOV: 498235, 129367); Nemesapáti, 2013.04.15. (EOV: 491663, 170519); Oltárc, 2014.01.14. (EOV: 479903, 131365, lv.), 2014.11.25. (EOV: 481924, 134549, lv.), 2016.07.10. (EOV: 479837, 130684, 1v.); Ortaháza, 2013.05.10. (EOV: 468248, 143829); Pacsa, patak völgy, 2016.01.30. (EOV: 498331, 156060); Pácsony, 2013.05.09. (EOV: 483566, 185584, lv.); Padár, 2016.03.12. (EOV: 497070, 170208); Páka, 2013.05.15. (EOV: 468057, 137221, lv.); Pat, 2014.02.18. (EOV: 506880, 125003, lv.); Pölöske, Kismezőpuszta, 2012.10.31. (EOV: 488398, 158071, im.); Pölöske, 2013.04.29. (EOV: 487042,153129, im., EOV: 487806, 154129, lv.,), 2013.05.13. (EOV: 488304, 159711), 2013.09.24. (EOV: 486762, 152661, 1v.), 2016.05.07. (EOV: 487910, 154084), 2016.03.19. (EOV: 483975, 156748); Pötréte, 2013.10.29. (EOV: 489417, 147211, lv.); Pusztaszentlászló, 2012.11.28. (EOV: 481658, 146784, lv.); Ramocsa, 2013.05.14. (EOV: 451845, 161407); Resznek, 2013.04.12. (EOV: 450921, 149792, lv.); Rezi, Rezi-erdő, 2017.03.25, (EOV: 510776, 171309, pup.); Sármellék, Lajosházi major, 2012.11.26. (EOV: 503662, 155827, im., EOV: 503518, 155759, lv.); Sármellék, 2014.11.26. (EOV: 503404, 154996, 1v.), 2016.03.19. (EOV: 502955, 157370); Sormás, 2013.04.24. (EOV: 485499, 129910, lv., EOV: 485499, 129910, 1v.); Söjtör, 2012.11.28. (EOV: 482215, 147746, lv.), 2013.04.18 (EOV: 483621, 147755, im., lv., EOV: 484085, 146156, im., lv.); Surd, 2016.01.30. (EOV: 491686, 114280); Szentgyörgyvár, 2013.04.29. (EOV: 502997, 158730, lv.), 2013.10.14. (EOV: 503325, 160092, lv., EOV: 502571, 164238, 1v.); Szepetnek, 2013.10.30. (EOV: 486292, 118992, 1v.); Tormafölde, Centrálé, 2012.05.07. (EOV: 462525, 136122, lv.); Tormafölde, Vétyem, 2013.05.15. (EOV: 465335, 137816, lv.); Tormafölde, 2016.09.30. (EOV: 462401, 134559); Tornyiszentmiklós, 2014.12.18. (EOV: 458298, 131824, lv.); Tótszerdahely, Barnica, 2012.11.10. (EOV: 476219, 118420, im.); Tótszerdahely, 2013.10.21. (EOV: 476417, 118519, lv.); Vállus, Pórag-hát, 2017.05.10, (EOV: 517008, 167359, im.); Vasboldogasszony, 2012.11.21. (EOV: 484584, 176916, im.); Vaspör, 2013.05.07. (EOV: 469217, 175672, im.); Vállus, 2017.05.10. (EOV: 517008, 167359, im.); Várvölgy, 2012.01.04. (EOV: 515242, 170613, im.), 2016.10.28. (EOV: 515556, 170719, lv.); Zalaapáti, 2012.11.22. (EOV: 502425, 155682, lv. EOV: 501991, 154053, lv.); Zalabér, 2013.04.08. (EOV: 497302, 183008, lv.); Zalacséb, 2013.04.16. (EOV: 469731, 171727, 1v.); Zalaegerszeg, Csács, 2013.04.19. (EOV: 485414, 167614, lv.); Zalaigrice, 2012.11.22. (EOV: 493888, 156183, lv., EOV: 493050, 158556, lv.); Zalakaros, 2016.07.24. (EOV: 503426, 137617); Zalakomár, 2013.03.31. (EOV: 507145, 128474, lv., EOV: 506389, 128829, lv.); 2013.10.18. (EOV: 504545, 129972, lv.), 2014.04.01. (EOV: 507418, 128624, 1v.), 2014.07.28. (EOV: 506929, 130803, 1v.), 2014.08.11. (EOV: 506057, 128804, lv.), 2016.03.12. (EOV: 505715, 128390); Zalalövő, 2013.04.16. (EOV: 465543, 170563, EOV: 465447, 170114, lv.), 2013.05.08. (EOV: 461307, 168916, im., EOV: 461457, 166784, im., EOV: 460773, 166807, lv., EOV: 461003, 164173, 1v., im.), 2013.06.26. (EOV: 460782, 168852, lv.); Zalaszántó, 2017.03.25. (EOV: 510776, 171309, im.); Zalaszántó, Gyöngyös-patak-mente, 2012.01.12. (EOV: 513096, 172960, im.); Zalaszántó, Kovácsi erdő, 2012.03.25. (EOV: 510594, 175040, im.); Zalaszegvár, 2013.08.04. (EOV: 511243, 196244, lv., EOV: 511628, 196930, lv.); Zalaszentbalázs, 2013.04.18. (EOV: 483945, 143429), 2016.10.25. (EOV: 483867, 141400, lv., EOV: 483786, 141749, lv., EOV: 483795, 141770, lv.); Zalaszentiván, 2013.10.15. 
(EOV: 485242, 170822, lv.), 2014.01.13. (EOV: 486687, 173635, im.); Zalaszentjakab, 2015.03.20. (EOV: 503156, 129489, lv.); Zalaszentlőrinc, 2012.11.21. (EOV: 484796, 176391, lv.); Zalaszentmihály, Bebesi-rét, 2012.10.31. (EOV: 492489, 157343, im.); Zalaszentmihály, 2013.10.29. (EOV: 489127, 153606, 1v.); Zalaszombatfa, 2013.04.12. (EOV: 451560, 146993, lv., EOV: 451580, 146927), 2014.12.18. (EOV: 450802, 145126, lv.); Zalavár, 2015.04.24. (EOV: 503619, 150630, im., EOV: 503585, 151852, lv.)

\section{Rhysodes sulcatus (Fabricius, 1787)}

\section{Somogy megye}

Babócsa, 2015.04.14. (EOV: 519061, 79003); Balatonboglár, Boglári Nagy-berek, 2013.03.13. (EOV: 542636, 159139), 2013.03.20. (EOV: 543323, 158442); Balatonfenyves, Községi legelö, 2013.03.20. (EOV: 527507, 151530); Balatonkeresztúr, Felsőmelléki-legelő, 2013.05.15. (EOV: 522813, 151453); Barcs, Darányiborókás, 2015.04.18. (EOV: 532733, 71130, EOV: 532488, 72585, EOV: 534456, 72101, EOV: 534438, 72128, EOV: 534010, 71989, EOV: 534446, 70220, EOV: 534419, 70205, EOV: 534620, 69662); Barcs, KisBók, 2015.04.18. (EOV: 531635, 68684, EOV: 531849, 68293); Barcs, Ferenc-telep, 2015.04.14. (EOV: 522656, 71679); Bélavár, Kerék-hegy, 2015.04.13. (EOV: 508593, 90761), 2018.04.15. (EOV: 508633, 90838); Bolhás, 2013.04.07. (EOV: 512698, 107033); Böhönye, 2013.07.17. (EOV: 526319, 123846); Böhönye, Cifra malom, 2017.07.15. (EOV: 527551, 121925, EOV: 527546, 121913, EOV: 528260, 122317); Böhönye, Dávod-puszta, 2017.07.15. (EOV: 526966,120873); Böhönye, Trangolion, 2017.07.15. (EOV: 527212, 119333, EOV: 527050, 120383, EOV: 526773,120127); Buzsák, Terlakóca, 2014.02.24. (EOV: 538168, 147440); Buzsák, Medvogya-patak-völgye, 2013.01.10. (EOV: 535108, 144277); Buzsák, Kundpuszta, 2013.05.07. (EOV: 533917, 146246); Buzsák, Borjú-sziget, 2013.05.07. (EOV: 536131, 152026); Csurgó, Lankóci-erdő, 2015.04.12. (EOV: 496245, 101537, EOV: 498845, 99561); Gamás, Vadéi-erdő, 2013.03.11. (EOV: 554350, 141974); Gyékényes, Lankóci-erdő, 2015.04.12. (EOV: 495983, 100877); Hács, Gárdony, 2013.05.08. (EOV: 546852, 141543); Hetes, Pati-erdő,2013.04.13. (EOV: 544346, 115868, EOV: 544202, 116071, EOV: 543792, 116793), 2013.04.30. (EOV: 543607, 117235); Hosszúvíz, 2013.03.23. (EOV: 526923, 131051); Hosszúvíz, Cserfekvés, 2013.03.23. (EOV: 529377, 130458, EOV: 528532, 129043); Iharos, 2013.04.07. (EOV: 505653, 111304); Iharosberény, Máhomoki-erdő, 2013.04.13. (EOV: 505296, 113560); Istvándi, Szállás-tói erdő, 2015.04.18. (EOV: 537540, 76244); Kaszó, 2013.04.07. (EOV: 511241, 108062, EOV: 509715, 109547, EOV: 507910, 110959, EOV: 510533, 109114); Kisberény, 2013.05.08. (EOV: 542625, 143585); Lengyeltóti, Kék-tó, 2013.03.18. (EOV: 543706, 148389); Marcali, 2017.02.20. (EOV: 526666, 136539, EOV: 526668, 136533, EOV: 526861, 136814); Marcali, Nagy-Gyóta, 2013.03.09. (EOV: 528505, 135099, EOV: 528241, 134467); Marcali, Nagy-Gyótai-erdő, 2017.02.20. (EOV: 528394, 136124), Marcali, Gyótai-erdő, 2013.03.09. (EOV: 527849, 133881), 2013.03.23. (EOV: 526263, 132287), 2017.03.09. (EOV: 526915, 132926, EOV: 527301,132933); Marcali, Gyóta-puszta, 2017.02.20. (EOV: 527797, 136553); Mesztegnyő, Alsójárás, 2013.07.17. (EOV: 526920, 126285); Mesztegnyő, Vad-kerti-erdő, 2017.04.08. (EOV: 532011, 128631, EOV: 532302, 128376); Nikla, Kozma-hegy, 2014.07.15. (EOV: 532662, 135745); Péterhida, 2015.04.14. (EOV: 519852, 74956); Rinyaszentkirály, Magas-erdő, 2013.07.14. (EOV: 521238, 94624); Somogysámson, Felső-Gyulavár, 2014.03.27. (EOV: 518446, 143066, EOV: 517706, 141822), 2015.06.25. (EOV: 518496, 143180); Somogyudvarhely, 2015.04.13. (EOV: 505592, 95459, EOV: 505506, 95636); Somogyudvarhely, Nagy-erdő, 2013.07.15. (EOV: 509232, 95253); Somogyvár, Vityai-erdő, 2013.07.09. (EOV: 547442, 140261, EOV: 547553, 141891); Szabás, Szatasi-Rinya-part, 2013.07.14. (EOV: 525130, 103471); Szenta, 2013.04.07. (EOV: 508145, 110538, EOV: 505411, 106776, EOV: 506291, 104695), 2013.04.30. (EOV: 510866, 99465), 2013.07.07. (EOV: 508266, 110272, EOV: 508298, 110282, EOV: 506847, 104539); Szenta, Nagy erdő, 2013.04.30.(EOV: 511330, 98673); Szenta, Nagy-Krató-erdő, 2013.07.18. (EOV: 508793, 102646); Zákányfalu, Izidorus-patak, 2013.04.30. (EOV: 488681, 106387); Zselickisfalud, Enyezdi-erdő, 2014.08.10. (EOV: 551450, 96984)

\section{Vas megye}

Kőszeg, Hármas-patak mente, 2015.08.01. (EOV: 455695, 229410); Kőszeg, Stájer-házak, 2018.04.17. (EOV: 455150, 228358, EOV: 455173, 228428); Kőszeg, Stájer-patak mente, 2015.08.01. (EOV: 455083, 228484)

\section{Veszprém megye}

Bakonyszücs, Huszárokelőpuszta, 2018.05.04. (EOV: 547759, 220109), 2018.05.08. (EOV: 547959, 220191); 


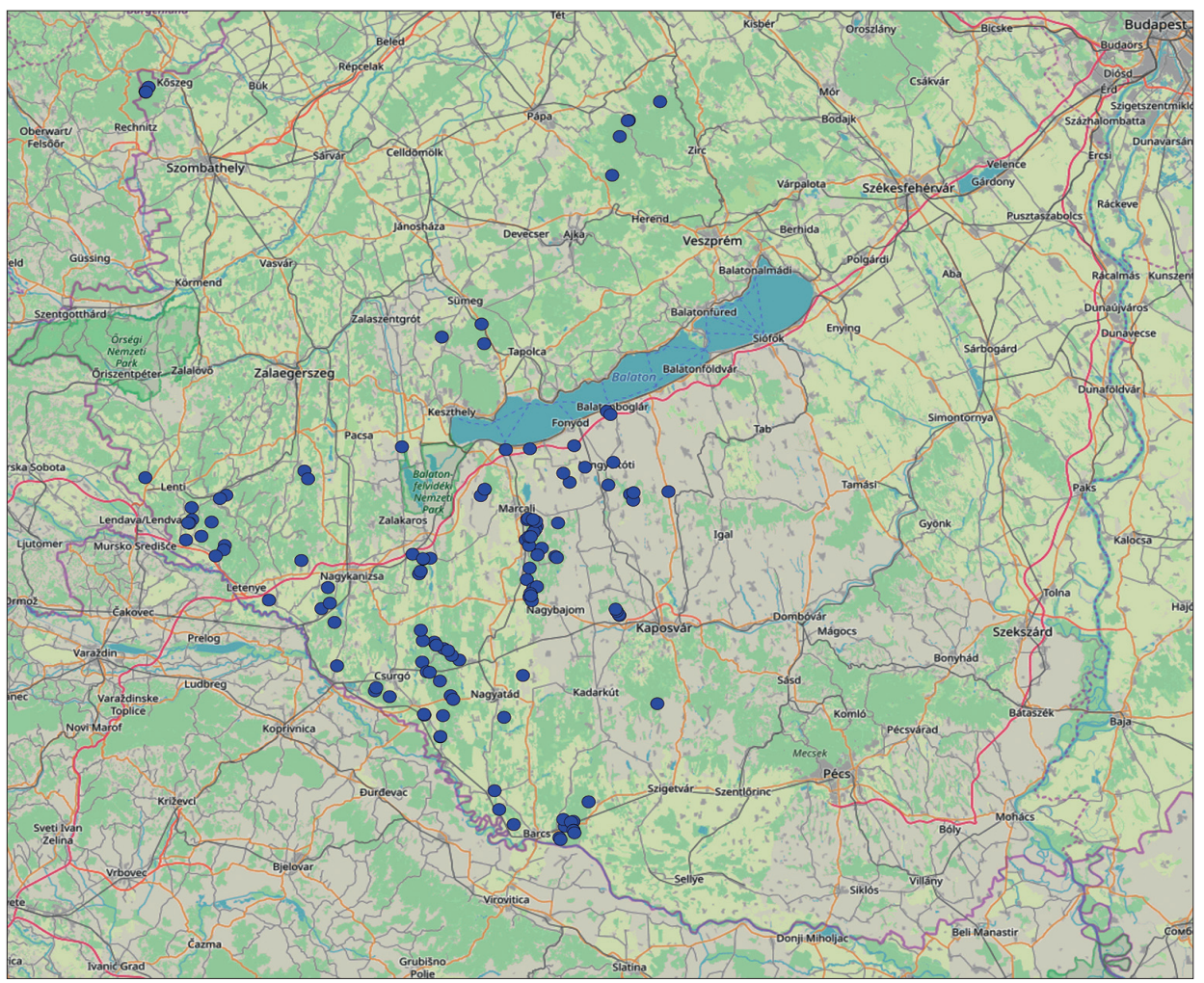

5. ábra: A kerekvállú állasbogár (Rhysodes sulcatus) előfordulási adatai

Fenyőfö, Szentlászlói-erdő, 2018.05.10. (EOV: 554036, 223980); Németbánya, 2018.05.18. (EOV: 544545, 208758); Sümeg, Sarvaly-erdő, 2016.10.28. (EOV: 518651, 178003, EOV: 518654, 178007); Ugod, Hubertlak, 2018.05.18. (EOV: 546151, 216836); Uzsa, Istvándi-erdő, 2016.10.28. (EOV: 519069, 173892)

\section{Zala megye}

Belsősárd, 2013.04.12. (EOV: 452372, 147442); Csörnyeföld, 2016.09.30. (EOV: 465576, 130418); Csörnyeföld, Basai-erdő, 2012.05.07. (EOV: 467425, 132610), 2014.11.13. (EOV: 467190, 131663); Dobri, 2016.09.30, (EOV: 462909,134703); Esztergályhorváti, 2015.04.24. (EOV: 502567, 152520); Fityeház, 2013.10.30. (EOV: 485965, 118642); Galambok, 2015.04.13. (EOV: 505265, 125513, EOV: 505578, 126092); Kerkateskánd, fás legelő, 2014.12.18. (EOV: 461172, 140819); Lovászi, 2013.05.10. (EOV: 461196, 138273), 2014.11.13. (EOV: 460653, 137512, EOV: 460432, 137604); Nagykanizsa, 2016.04.16. (EOV: 488442, 115660); Nagykanizsa, Bajcsa, 2013.04.26. (EOV: 487341, 123086), 2016.09.29. (EOV: 487641, 119771); Páka, 2013.05.10. (EOV: 468046, 143222, EOV: 466791, 142568); Rigyác, 2014.04.23. (EOV: 482309, 128976); Söjtör, 2013.04.18. (EOV: 483433, 147895), (EOV: 484098, 146217); Szepetnek, Hidegkúti-erdö, 2012.04.27. (485 697, 121022); ; Tormafölde, 2013.05.15. (EOV: 465002, 137623); Tornyiszentmiklós, 2013.05.10. (EOV: 459876, 134002); Tótszerdahely, 2015.04.30. (EOV: 475721, 120760); Zalakomár, 2013.10.18. (EOV: 504088, 129738), (EOV: 506164, 128636), 2013.11.22. (EOV: 507545, 128798), 2014.08.11. (EOV: 506119, 128727); Zalaszántó, Kovácsi-erdő, 2016.10.28. (EOV: 510890, 175476) 


\section{Értékelés}

A skarlátbogár (Cucujus cinnaberinus) vizsgálataink során 556 ponton került elő. A faj szinte valamennyi vizsgált Natura 2000 területen megtalálható volt, sok helyen nagyobb állományait találtuk.

A faj a vizsgált területen általánosan elterjedt és gyakori, az 4. ábrán látható adathiányos területek nem a faj, hanem a vizsgálatok hiányát jelöli. Előfordulását tapasztalataink szerint az élőhely fajtája, az erdőtípus és a faállomány kora csak kevéssé befolyásolja, az elsődleges tényező ennél a fajnál is a megfelelő mennyiségü és minőségü holt fa jelenléte.

A faj fö tápnövényei a nyár és füzfajok, valamint az erdei fenyő, de számos más fafajban is megtalálható volt.

Minden olyan élőhelyen előfordulhat, ahol száradó, vagy kiszáradt fák találhatóak, az élőhely fajtája nem befolyásolja. Szinte minden fafajban elöfordulhat, azonban előnyösebbek számára a vastagabb kérgü fafajok (nyár, füz, fenyő, idős éger), ezek korhadási tulajdonságai is kedvezőbbek és nagyobb védelmet is nyújtanak a telelö bogaraknak és lárváknak. A nedvesebb mikroklímájú élőhelyeken gyakoribbak a faj számára megfelelő állapotú holt fák. A jellemzően erdős területek mellett a faj számára alkalmas élőhelyet jelentenek az erdősávok, a magányos fák, fasorok és facsoportok is. Ezek sokszor kedvezőbbek is, mert nem, vagy csak igen ritkán kezelik, faállományuk kevésbé értékes, ezért gyakran sokkal több holtfa található bennük, mint egy kezelt erdőben.

A témával foglalkozó szerzők mindkét faj esetében a veszélyeztetettséget elsősorban az élöhelyek csökkenése okozza (HorÁk \& СНовот 2009, HorÁk et al. 2010). Tapasztalataink alapján megállapíthatjuk, hogy a fajok számára alkalmas élöhelyek csökkenése kétségtelenül tapasztalható. A klimatikus változások, a csapadék mennyiség csökkenése, valamint a csapadékeloszlás megváltozása, illetve az emberi beavatkozások hatására az élőhelyek szárazodása kimutatható. A faj számára alkalmas megfelelően

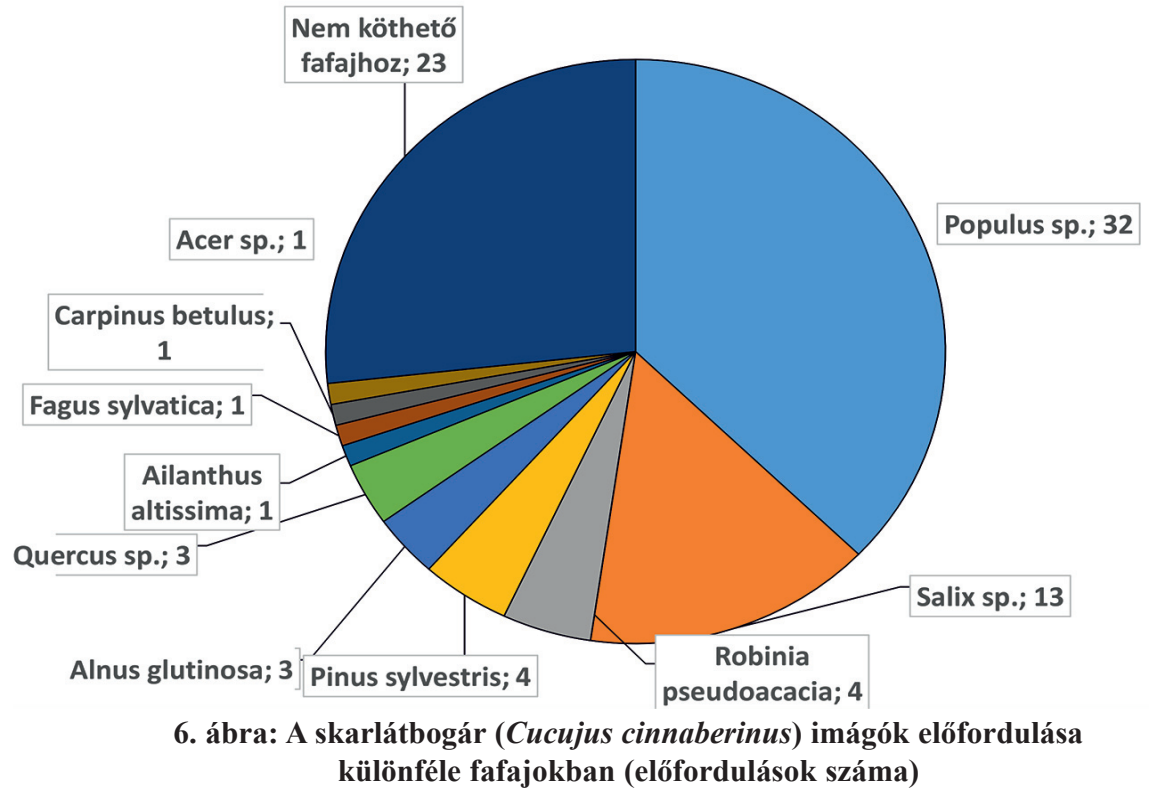




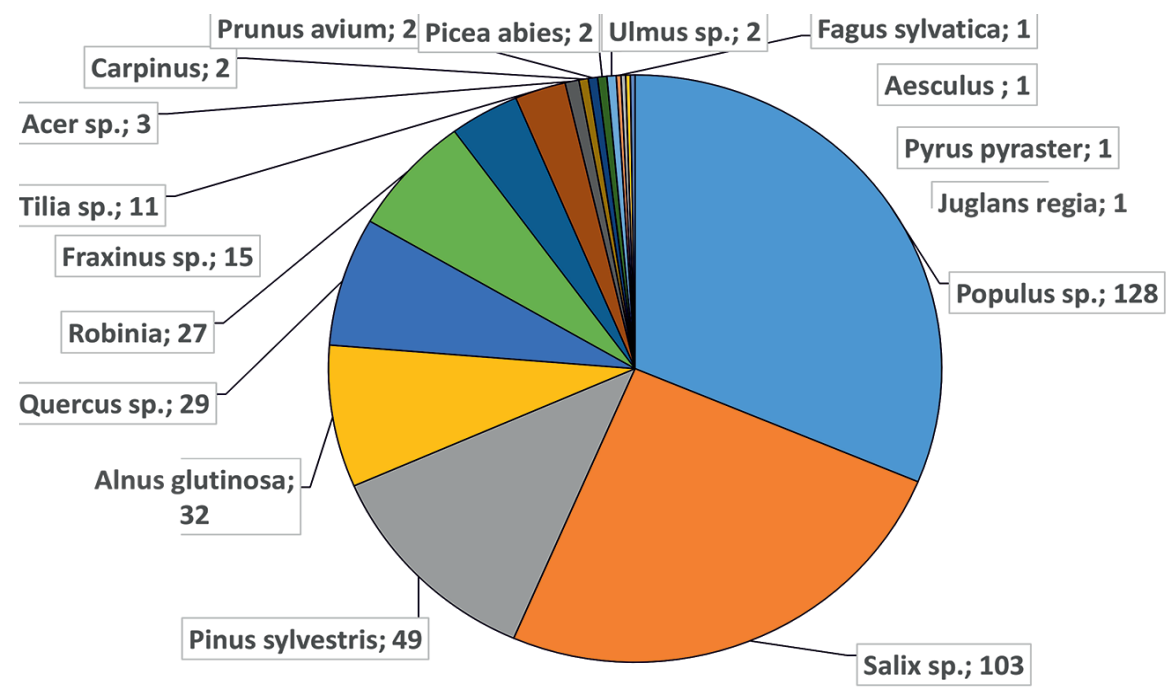

7. ábra: A skarlátbogár (Cucujus cinnaberinus) lárvák előfordulása különféle fafajokban (előfordulások száma)

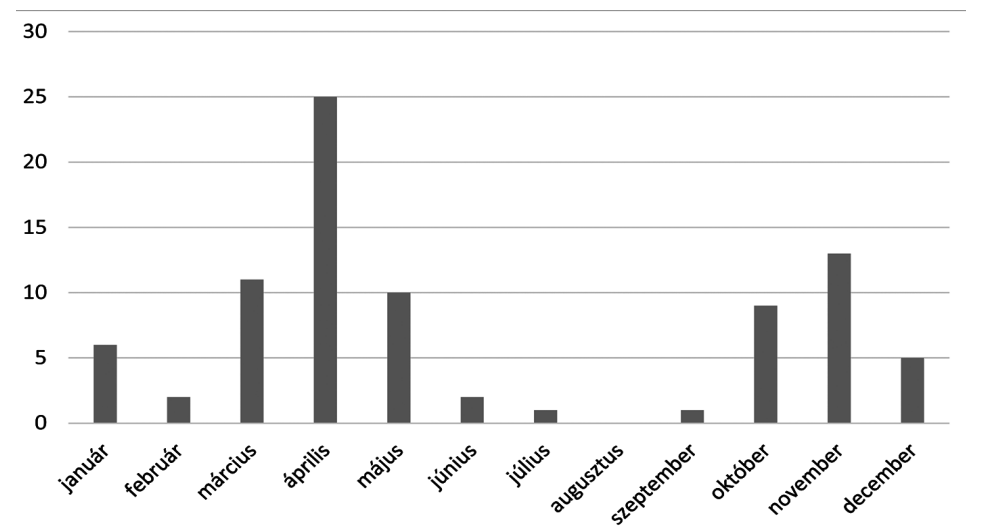

8. ábra: A skarlátbogár (Cucujus cinnaberinus) imágók előfordulási adatai havonkénti bontásban

átkorhadt, gombákkal átszőtt holt faanyag csak elegendően nedves körülmények között alakul ki, így ez kétségtelenül fontos tényezö.

Mivel az általunk vizsgált területek jelentős részén megtalálhatóak a fajok számára alkalmas erdőtípusok és élöhelyek, azonban egyes területeken jelenlétüket nem sikerült igazolni, illetve ritkábbnak bizonyultak, egy további megállapítást is tehetünk. A alkalmas élőhelyeken való előfordulást alapvetően a megfelelő mennyiségü és minőségü holtfa jelenléte határozza meg, vagyis az általunk vizsgált területeken ezt tekinthetjük elsődleges korlátozó tényezőnek. Az egyes területeken tapasztalt erdőgazdálkodási gyakorlat jelentősen különböző és számos módon befolyásolja a fajok kilátásait. Ide sorolhatjuk a nagyterületü homogén keményfás monokultúrák kialakítását, a vízfolyások mentén, vagy nedvesebb élőhely foltokban elegyként megjelenő, rövidebb vágáskorú 


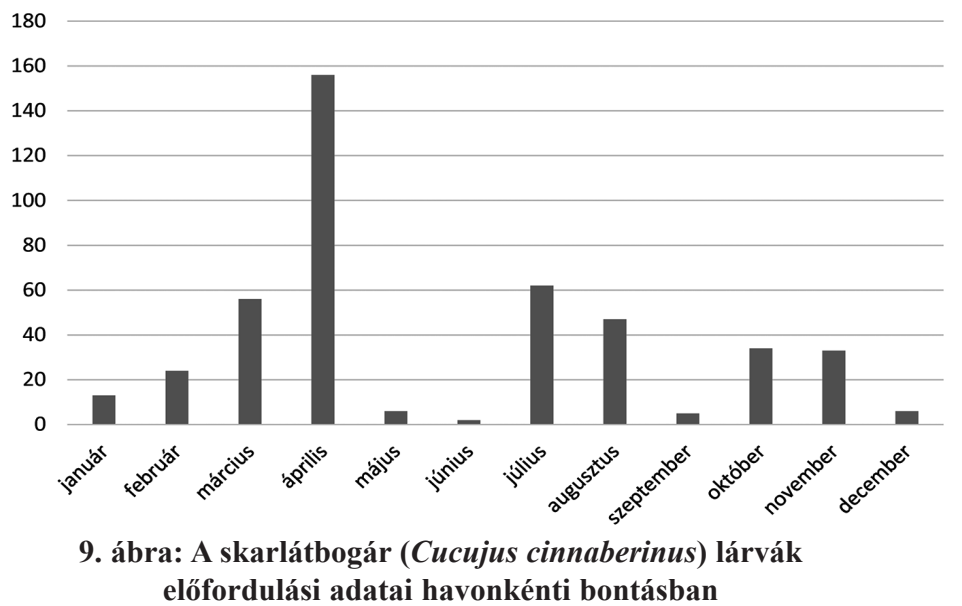

puhafa fajok (éger, füz, nyár) eltávolítását. Hasonló problémát jelent egyes területeken a holt faanyag szinte teljes hiánya, amelyet az indokolatlan egészségügyi-, vagy értékmentés címen végzett termelések okoznak. Ezeknek egészségügyi haszna csekély, az így nyert alacsony értékü faanyag miatt tulajdonképpen gazdaságilag is nehezen igazolhatóak, viszont az összes szaproxilofág rovarfaj kilátásait súlyosan veszélyeztetik. Ezért az elsődleges természetvédelmi cél, hogy az alkalmas élöhelytípusok esetében, lehetőleg folyamatosan megfelelö mennyiségü holt faanyag legyen a területen, és ezt nem csak a véghasználatok esetén, hanem már az előhasználatok során is elö kell írni. A gyérítések és véghasználatok során legalább $5 \mathrm{~m}^{3} /$ ha álló és/vagy fekvő holtfa jelenlétének biztosítása szükséges. A Natura 2000 területeken, az arra alkalmas erdőrészletekben a véghasználatok során, minden esetben - a jogszabályok adta lehetőségeket kihasználva - olyan hagyásfa csoportokat kell kialakítani, amelyek figyelembe veszik a faj érdekeit

A kerekvállú állasbogarat (Rhysodes sulcatus) 130 mintavételi ponton mutattuk ki. A faj nagy számban került elő Belső-Somogyból és Dél-Zalából, a Mura és Dráva mentéröl. Leggyakoribbnak ezeken a síkvidéki területeken bizonyult, ahol a hullámos, döntően homokfelszín széles völgyeiben nagy számban találunk vizes élőhelyeket, láp- és egyéb üde erdőtípusokat, míg a magasabb térszinteken a korábbi homokpuszták beerdősítése során kialakult erdei fenyveseket. Ezeknek az élőhelyeknek mindegyike kiválóan alkalmas a faj számára, megfelelő mennyiségü és minőségü holtfa esetén gyakori előfordulású.

Ezeken kívül néhány további mintavételi helyeken is megtalálható volt, azonban ezeken a területeken jóval ritkábbnak bizonyult. A szubmontán jellegű dombvidékeken (Zselic és Zalai-dombvidék egyes részei), valamint a hegyvidéki területeken (Bakony, Keszthelyi- és Köszegi-hegység) elsősorban a vízfolyások mentén és a nedvesebb völgytalpak égereseiben és bükköseiben, illetve az alacsonyabb régiók erdei fenyveseiben találtuk. Ezek az előfordulások azonban elszigeteltek, az alkalmas élöhelyek száma és mérete rendkívül kicsi.

Tapasztalataink szerint a kerekvállú állasbogár (Rhysodes sulcatus) jelenlét/hiány kimutatása egyeléssel, az alkalmas korhadó fák bontásával és kérgezéssel hajtható végre. Az imágók legkönnyebben április-június között találhatóak meg, de szinte az egész éven át megfigyeltjük egyedeit. A téli időszakban az áttelelő egyedek a földön fekvő holtfában, a mélyebb rétegekben, általában repedések mentén és más rovarok által készített 


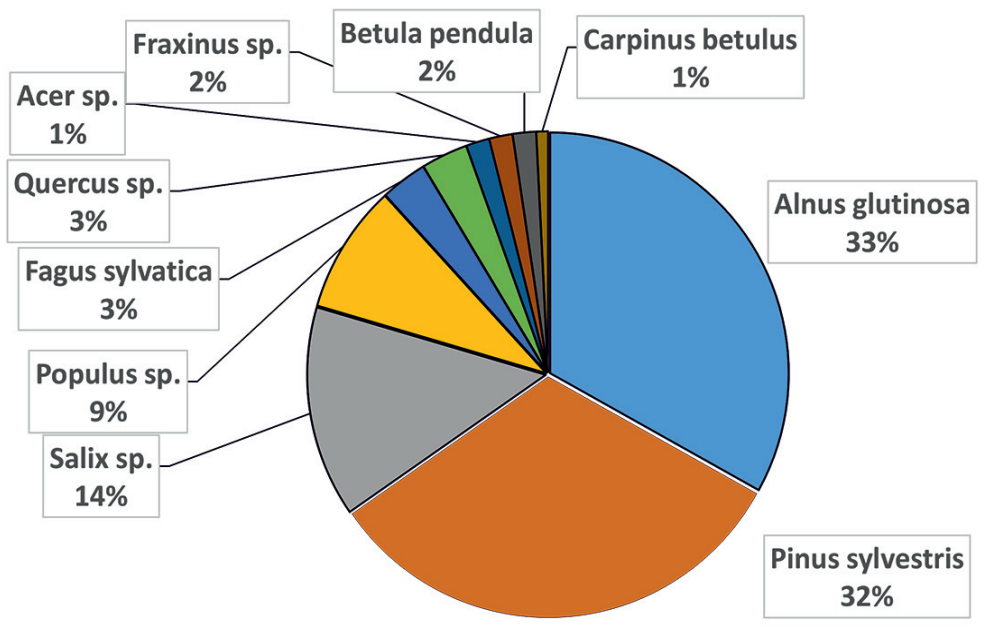

10. ábra: A kerekvállú állasbogár (Rhysodes sulcatus) előfordulása különféle fafajokban

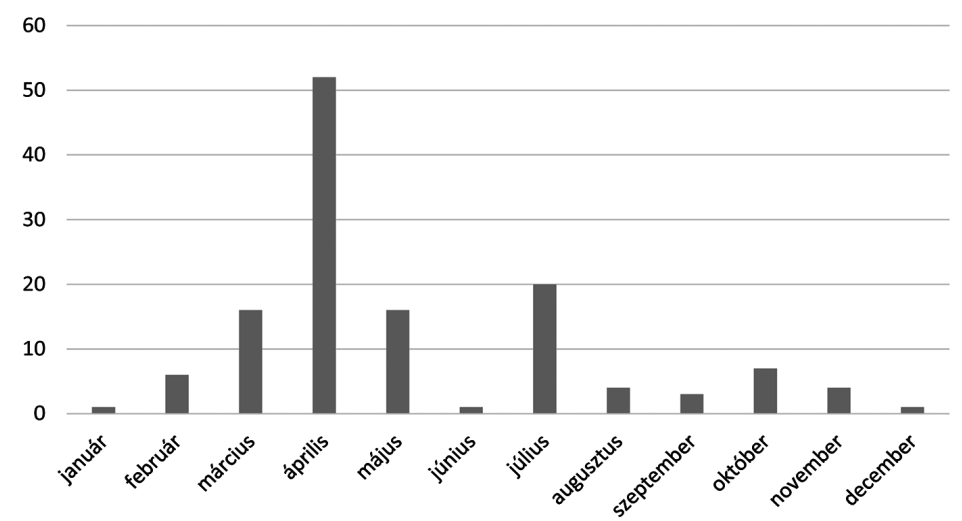

11. ábra: A kerekvállú állasbogár (Rhysodes sulcatus) előfordulási adatai havonkénti bontásban

járatokban telelnek, gyakran csoportosan több egyed. A tavaszi-koranyári időszakban gyakran közvetlenül a kéreg alatt találhatóak a bogarak, illetve ritkán farakáson mászkáló egyedeket is megfigyelhetők, így felkutatásuk ilyenkor a legkönnyebb, illetve kisebb élőhely rongálással is jár.

Előfordulását tapasztalataink szerint az élőhely fajtája, az erdőtípus és a faállomány kora csak másodlagosan befolyásolja, az elsődleges tényező a megfelelő mennyiségü és minőségü holt fa jelenléte. Az imágók és lárvák egyaránt gombafogyasztók, élőhelyként a gombákkal jól átszőtt, korhadó fák szolgálnak. Természetesen az eltérő korhadási tulajdonságaik miatt az egyes fafajok jelenléte nem közömbös, azonban ezek gyakran csak elegyként, színező elemként fordulnak elő, míg az állományalkotó főfajok, mint a gyertyán, vagy tölgyfajok csak igen ritkán alkalmasak a faj számára. Ismereteink szerint 
elsősorban üdébb erdőkben, patak völgyekben és vizes élőhelyeken lehetett rá számítani, ahol a holt fák korhadása nedves körülmények között történik. Bár nem kizárólagosan, de tapasztalataink szerint elönyben részesíti a „vörösen korhadt” faanyagot. Vizsgálatunkban jelentős számban került elő erdei fenyőből is, amelyre még száraz termőhelyeken is jellemző a vörös korhadás.

\section{Köszönetnyilvánítás}

Köszönetet mondunk áldozatos munkájukért a mintavételezésben részt vevő kutatóknak és kollégáknak, Merkei Gábornak, Scherer Zoltánnak, Kenéz Istvánnak, Lelkes Andrásnak, Magyari Máténak és Vig Károlynak. Szeretnénk megköszönni a SvájciMagyar Hozzájárulás program (SH/4/12), valamint az érintett Örségi-, Duna-Dráva- és Balaton-felvidéki Nemzeti Park Igazgatóságok kutatásra nyújtott támogatását. 


\section{Irodalom}

ÁDÁm L. 1994: A Mátra Múzeum bogárgyűjteménye, Rhysodidae-Gyrinidae (Coleoptera). - Folia historiconaturalia Musei Matraensis 19: 129-136.

HorÁk, J. \& Сновот, K. 2009: Worldwide distribution of saproxylic beetles of the genus Cucujus Fabricius, 1775 (Coleoptera: Cucujidae). - In Buse J, Alexander KNA, Ranius T, Assmann T (Eds) Saproxylic Beetles - their role and diversity in European woodland and tree habitats. - Proceedings of the 5th Symposium and Workshop on the Conservation of Saproxylic Beetles. Pensoft Publishers, Sofia-Moscow: pp. 189-206.

Horák J., Vavrova E. \& Сновот K. 2010: Habitat preferences influencing populations, distribution and conservation of the endangered saproxylic beetle Cucujus cinnaberinus at the landscape level. -European Journal of Entomology 107: 81-88.

Kovács T., DomboróczKi G. \& URBÁN L 2015: Ritka és természetvédelmi szempontból jelentős bogarak (Coleoptera) Lillafüred környékéről. - Folia historico-naturalia Musei Matraensis 39: 55-61.

Kovács T., Bátori G., Huber A. \& Urbán L. 2017: Ritka és természetvédelmi szempontból jelentős bogarak (Coleoptera) a Bükk, az Aggteleki-karszt és a Putnoki-dombság környékéről. - Folia historico-naturalia Musei Matraensis, 41: 167-180.

Kuthy D. 1897: Ordo. Coleoptera. - In: AMagyar Birodalom Állatvilága (Fauna Regni Hungariae). III. Arthropoda. (Insecta. Coleoptera.). Királyi Magyar Természettudományi Társulat, Budapest, 213 pp.

Méndez, M., Dodelin, J., Petrakis, P., Schlaghamersky, J. \& Nardi, G. 2010: Rhysodes sulcatus. The IUCN Red List of Threatened Species 2010: e.T157582A5100245. Downloaded on 05 September 2018.

MerkL O. 2008: Skarlátbogár (Cucujus cinnaberinus). Zárójelentés. A madárvédelmi (79/409/EK) és az élőhelyvédelmi (92/43/EK) irányelveknek megfelelő monitorozás előkészítése című Átmeneti Támogatás projekt (2006/018-176-02-01). Kézirat. Környezetvédelmi és Vízügyi Minisztérium, Budapest

Merkl O. 2014: Skarlátbogár Cucujus cinnaberinus (Scopoli, 1763). In: Haraszthy L. (szerk.): Natura 2000 fajok és élőhelyek Magyarországon. Pro Vértes Közalapítvány, Csákvár: 254-256.

Nieto, A., Mannerkoski, I., Putchkov, A., Tykarski, P., Mason, F., Dodelin, B., Horák, J. \& Tezcan, S. 2010: Cucujus cinnaberinus. The IUCN Red List of Threatened Species 2010: e.T5935A11921415. http:// dx.doi.org/10.2305/IUCN.UK.2010-1.RLTS.T5935A11921415.en. Downloaded on 05 September 2018.

RozNER Gy. \& LőKKös A. 2017: Útmutató Natura 2000 fajok monitorozásához, xilofág bogarak. - Somogy Természetvédelmi Szervezet, Somogyfajsz pp. 38-45.

Rozner Gy., Lőkkös A., Merkei G., Scherer Z., KenÉz I., Lelkes A. \& Vig K. 2016: Skarlátbogár Cucujus cinnaberinus (Scopoli, 1763). - In: Haraszthy L. \& SÁfián Sz. (szerk.) Védett állatfajok elterjedési atlasza Vas, Zala és Somogy county Natura 2000 területein. Somogy Természetvédelmi Szervezet, Somogyfajsz: pp. 52-53.

Rozner Gy., Lökkös A., Merkei G., Scherer Z., Kenéz I., Lelkes A. \& Vig K. 2016: Kerekvállú állasbogár Rhysodes sulcatus (Fabricius, 1787). - In: HARASZTHY L. \& SÁFIÁN Sz. (szerk.): Védett állatfajok elterjedési atlasza Vas, Zala és Somogy county Natura 2000 területein. Somogy Természetvédelmi Szervezet, Somogyfajsz pp. 42-43.

SzÉL, Gy. 1996: Rhysodidae, Cicindelidae and Carabidae (Coleoptera) from the Bükk National Park. - In: MahunKa, S. (ed.): The Fauna of the Bükk National Park, II. Magyar Természetudományi Múzeum, Budapest, pp. 159-222.

SzÉl Gy. \& KuTASi Cs. 2014: Kerekvállú állasbogár Rhysodes sulcatus (Fabricius, 1787). In: HaraszThy L. (szerk.) Natura 2000 fajok és élőhelyek Magyarországon. - Pro Vértes Közalapítvány, Csákvár pp. 228230.

Vrezec A, Ambrožıč S, Kobler A, Kapla A, de Groot M. 2017: Cucujus cinnaberinus (Scopoli, 1763) at its terra typica in Slovenia: historical overview, distribution patterns and habitat selection. - In: Campanaro A, Hardersen S, Sabbatini Peverieri G, Carpaneto GM (Eds) Monitoring of saproxylic beetles and other insects protected in the European Union. Nature Conservation 19: 219-229. 
